\title{
MAPPING OF THE PRECAMBRIAN BASEMENT IN THE FISKENÆSSET REGION, SOUTHERN WEST GREENLAND
}

\author{
Feiko Kalsbeek
}

The systematic mapping of the Fiskenæsset region, which began in 1970 (see previous GGU Reports of Activities) was continued in the period June to September. Apart from the author the following geologists took part: J. C. Escher (GGU), W. R. Fitches (Univ. Coll. of Wales, Aberystwyth), R. P. Hall (Portsmouth Coll. of Tech.), A. M. Hopgood (Univ. of St. Andrews), E. Kirsbo (Univ. of Copenhagen), J. S. Myers (GGU), G. A. G. Nunn (Univ. of Liverpool), R. P. E. Poorter (Univ. of Utrecht), J. Tonika (Geol. Surv. Prague), B. J. Walton (Portsmouth Coll. of Tech.), C. B. Zetterstrøm (Randers, Denmark). D. Heling (Univ. of Heidelberg) made an investigation of Recent sediments in the fjords and lakes (see this report) and A. Weidick (GGU) studied the Quaternary geology of the area (see this report). During the summer, a group of geologists from California Inst. of Technology, under the direction of G. J. Wasserburg visited the area to collect material for isotope studies.

The two-man field parties were served by two helicopters and the GGU motor cutters J. F. Johnstrup and Villiaumit operating from the base camp Midgård. As in previous years Ib Olsen (GGU) took care of most of the practical arrangements.

Mapping in most of the area between Grædefjord and $64^{\circ} \mathrm{N}$ was started during this summer and due to the favourable weather good progress was made with the work. Mapping as far as $64^{\circ} \mathrm{N}$ is hoped to be concluded in 1975 .

The general picture of the geology of the area, i.e. older amphibolites, anorthositic rocks and metasediments cut and migmatised by huge amounts of younger granitic to quartz-dioritic rocks, has not changed drastically. The existence of a basement older than the amphibolites and metasediments has still not been demonstrated. Granitic augen gneisses ('Ilivertalik granite') which cut earlier migmatites, but are themselves strongly folded and cut by younger granite material, occupy a large part of the terrain north of Grædefjord. Complications of the simplified picture seem to arise locally for example where strongly migmatised anorthosites occur side by side with hardly migmatised amphibolites, or where sheets of amphibolite lie within granitic augen gneiss. It is not always clear how such features should be interpreted. One possibility is that major amphibolites of different ages occur.

A simplified chronological scheme is presented in table 2. Correlations with the Godthåb terrain are tentative. Isotopic determinations of the age of the gneisses in the Fiskenæsset region meet with difficulties; the late phase of metamorphism 
seems to have upset isotopic evidence of older ages (R. T. Pidgeon, personal communication). Correlations by means of absolute age determinations are therefore difficult.

More information on the geology of the Fiskenæsset region may be found in a recent progress report - Rapp. Gronlands geol. Unders. 51, 1973.

Table 2. Simplified chronological scheme for the Precambrian of the Fiskenasset region with a similar scheme of the Godthåb region to the north for comparison.

\begin{tabular}{|c|c|c|c|}
\hline & Fiskencesset & & Godthåb \\
\hline (7) & $\begin{array}{l}\text { Different generations } \\
\text { of dolerite dykes }\end{array}$ & (age unknown) & $\begin{array}{l}\text { Different generations of } \\
\text { dolerite dykes }\end{array}$ \\
\hline (6) & $\begin{array}{l}\text { Younger phases of deformation, minor } \\
\text { migmatisation, intrusion of younger } \\
\text { granitic rocks, final metamorphism } \\
\text { locally under granulite facies conditions }\end{array}$ & $\Rightarrow 2800$ m.y. $\Leftarrow$ & $\begin{array}{l}\text { Local granulite facies } \\
\text { metamorphism (Nordland) }\end{array}$ \\
\hline (5) & $\begin{array}{l}\text { Intrusion of Ilivertalik group } \\
\text { of augen granites and associated rocks }\end{array}$ & (age unknown) & \\
\hline (4) & $\begin{array}{l}\text { Repeated deformation and migmatisation } \\
\text { of earlier rocks under amphibolite and } \\
\text { hornblende-granulite facies conditions }\end{array}$ & & $\begin{array}{l}\text { Continued plutonic } \\
\text { activity }\end{array}$ \\
\hline (3) & $\begin{array}{l}\text { Intrusion of tonalitic to granitic rocks, } \\
\text { migmatising the older rocks }\end{array}$ & $\stackrel{?}{\rightarrow} 3050$ m.y. $\leftarrow$ & Nûk gneisses \\
\hline (2) & $\begin{array}{l}\text { Older phase(s) of deformation and } \\
\text { metamorphism }\end{array}$ & & \\
\hline (1) & $\begin{array}{l}\text { Supracrustal amphibolites }+ \text { minor } \\
\text { pelitic and calcareous sediments with } \\
\text { intrusive anorthositic rocks }\end{array}$ & $\stackrel{?}{\rightarrow}$ (age unknown) & Malene supracrustals \\
\hline (0) & $\begin{array}{l}\text { Possible basement to (1), existence not } \\
\text { proven }\end{array}$ & $\stackrel{? 2}{\rightarrow} 3700$ m.y. $\Leftarrow$ & $\begin{array}{l}\text { Amîtsoq gneisses } \\
\text { Pre-Amîtsoq rocks }\end{array}$ \\
\hline
\end{tabular}

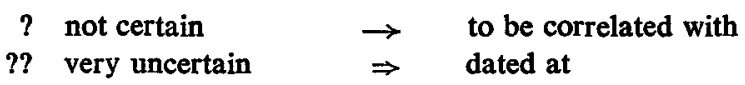

